\title{
Quality of Life among Hearing Loss Patients in Audiology Out Patient Clinics in Ain Shams University Hospitals
}

Shaimaa M Sultan ${ }^{\text {* }}$, Dalia G Sos ${ }^{2}$,Maha M Wadan ${ }^{2}$,Nagwa M Hazzaa ${ }^{3}$,Diaa M Abd El Hamid ${ }^{4}$ ${ }^{1} \mathrm{MOH}$, Egypt, ${ }^{2}$ Department of Community, Environmental and Occupational Medicine, ${ }^{3}$ Audiology, ENT Department, ${ }^{4}$ Family Medicine Department, Faculty of Medicine, Ain Shams University

\begin{abstract}
:
Background: Hearing loss(HL) among adults is one of the most common chronic illnesses worldwide Quality of life(QoL) might be affected if hearing loss is severe, usually causes difficulty in communication, affects cognitive, emotional status; and increased morbidity and mortality. The prevalence of hearing loss is growing because of increasing exposure to excessive noise, increased life expectancy, smoking, cardiovascular risks and infection. Objectives: This study aims to assess the quality of life (QoL) of hearing loss in outpatient clinics in Ain Shams University Hospitals and to recognize the factors which might affect the quality of life (QoL) in patients with hearing loss . Methods: This study is a cross sectional study. It was conducted from February 2018 to July 2018 on 311 patients with hearing loss attending audiology clinics located in Ain Shams University hospital. Data were collected using an interviewed questionnaire. Results: Out of 311 interviewed participants, $(52.1 \%)$ were females, $(24.1 \%)$ of the participants were between 18-29 years. Inflammation was found to be the main cause of hearing loss in $40 \%$ of the studied population. The environmental domain is the most affected QoL domain with the participants' hearing loss (Mean \pm S.D =56.1+11.4) with statistical significant effect of using hearing aids on QoL improvement.Conclusion: Screening high risk group of hearing impairment must be a crucial task in primary health centers activities for early diagnosis and intervention to prevent hearing loss and thus maintain good QoL in adults.
\end{abstract}

Key Words: Hearing loss, Hearing Aid, HHIA Egypt.

Introduction: Hearing loss is one of the most common sensory deficits in adults throughout the world; it is the third chronic disability after arthritis and hypertension. The impact of hearing loss may be profound, with consequences for the social, functional, and psychological well-being of the person. ${ }^{(1)}$ Nearly 250 million people suffer hearing loss in the world. Nearly $75 \%$ of sufferers are in developing countries. World Health Organization global in 2013 reported that one third of the elderly population aged 65 and above suffers hearing loss. Moreover, WHO predicts an epidemiological transition resulting in a rise between $18 \%$ and $50 \%$ from the year 2010 to $2020 .^{(2)}$

Many risk factors are behind the occurrence of hearing loss; among nonmodifiable risk factors as age, genetics, gender, and race., age plays the most significant role. In addition to modifiable risk factors; which encompass the nonuse of hearing protection, cigarette smoking, lack of exercise, low dietary intake of foods rich in

Corresponding author: E-mail: shimaasultan132@gmail.com 
antioxidant vitamins and minerals, the presence of diabetes or heart disease, and poor oral health. ${ }^{(3)}$

Development hearing loss leads to severe handicap that affects the sufferer's job, home and life with subsequent social and economic burden on the society. ${ }^{(4)}$ In Egypt, from 6 randomly selected governorates (Alexandria, Dakahlia, Luxor, Marsa-Matrouh, Minia and North Sinai), 4000 individuals were screened for hearing loss. The prevalence of hearing loss was $16 \%$ with no significant sex differences.

There were significant differences between the age groups and governorates: Marsa-Matrouh had the highest prevalence of hearing loss (25.7\%) and North Sinai the lowest $(13.5 \%)$; those $>$ or $=65$ years had the highest prevalence $(49.3 \%)$, but it was also high in those aged $0-4$ years $(22.4 \%) .{ }^{(4)}$

According to some studies, the impact of untreated hearing loss on adult population's quality of life (QoL) may be profound. It affects the domains of QoL(physical, social, environmental and psychological domain as well). It has been noted to reduce social interaction and functional activities. Other studies described presbycusis as a possible reason behind various adverse effects on the elderly psychological, social and physiological well-being. ${ }^{(5)}$

Hearing loss affects the capacity to contribute to social activities as it limits their engagement in communication and day to day activities. This results in a sense of seclusion from family, friends, and their community, emotional distress, embarrassment, frustration, anxiety, isolated depression and a sense of guilty being dependent. ${ }^{(6)}$

Under the hypothesis that hearing loss directly or indirectly leads to cognitive and physical decline, it is reasonable to hypothesize that hearing aids or other aural rehabilitative devices could mitigate these outcomes by reducing psychological, social, and emotional effects of hearing loss.

Industrialized societies have strategies for prevention and early detection for hearing impairment, while these programs progress slowly in developing countries where more than 30 million hearing aids are needed. ${ }^{(7)}$ The population-based data described the impact of hearing loss on QoL of Egyptian adults, and the effect of hearing aid usage on improving the QoL of these patients. The current study aimed to assess the quality of life (QoL) among adults suffering from hearing loss in outpatient clinics in Ain Shams University Hospitals. Also, it aimed at identifying the 
most important determinants affecting the quality of life (QoL).

Methods: A Cross sectional study was conducted on 311patients with hearing loss attending audiology clinics located in Ain Shams University hospital (El Demerdash) with the following criteria: Inclusion criteria:Age $>18$ years old, both gender are included, diagnosis of bilateral moderate hearing loss as measured by pure tone audiometry with hearing thresholds more than $40 \mathrm{~dB}$ HL.For those who use hearing aid should be regular in using it and satisfied with it. As regards the exclusion criteria: hearing loss due to wax, foreign bodies and acute otitis media, Patients with multiple disabilities (mental, visual, motor) and if the hearing loss status hinder the capability for understanding the questionnaire.

Sampling and sample size: A purposive sample was selected, all patients attending the auditory clinic and fulfilling selection criteria were recruited until fulfilling the targeted sample size (311 participants) of six months (from Februry 2018 to July 2018). Sample size was calculated using Epi-info 7.1 program putting in consideration that $28.1 \%$ of patients with hearing loss suffer from poor QOL (study carried out by AL-Mahbashi and Raja'a in 2011 in Yemen) at a confidence level of $95 \%$.
Study tools: Data were collected by interviewing the participants using two standardized questionnaires and set of sociodemographic data collection sheet that included diagnosis and causes of hearing loss. The two standardized questionnaire are as follow:

1- WHO QOL-BREF questionnaire ${ }^{(8)}$ to assess QoL among patients with hearing loss. It is encompasses of 26 questions, having two general questions, associated with quality of life and 24 representing four domains (physical health, psychological, social relations and environmental). Physical health (7 items: mobility, ability to carry out daily activities, energy, pain, need for medication or other treatment, sleep, and working capacity), psychological health (6 items: involves topics that reflect level of positive and negative feelings, self-esteem, body image, cognition, and spirituality), social relationships (3 items: individual's satisfaction with personal relationships, sex life, and social support), and environment ( 8 items: reflects individual's satisfaction with the physical environment and its safety, financial resources, opportunities to obtain health care services and information, opportunities to participate in leisure activities, and possibilities to use public transportation) 
A scoring system for each domain was calculated followed by calculating a transformed score from 0-100 scale, where 100 is the highest and 0 is the lowest in the quality of life.

2- The Hearing Handicap Inventory for Adults (HHIA) is a 25-item survey ${ }^{(9)}$ divided into 13-item emotional subscale and a 12-item socio-situational subscale.This tool is designed to measure the effects of hearing impairment on the emotional and social adjustment of adults. The HHIA total score categories is reflected as follow: $0-16 \%$ (no handicap), $18-42 \%$ (mild -moderate handicap), $44 \%$ and more (significant handicap).

Statistical analysis: Data were collected, tabulated and statistically analyzed via SPSS package for windows (statistical package for social science) program version 20, SPSS Inc., and Chicago, Illinois, USA. Qualitative data as (age categories, gender, educational level, occupational status, hearing loss level, laterality of hearing loss, hearing aid use) were expressed as frequency (n) and percentage (\%) while quantitative data as (scores of four domains of WHO QOL-BREF questionnaire) were expressed in mean and standard deviation. Independent-testwas used to compare quantitative dependent variables (scores of four domains of WHO QOL-BREF questionnaire) between two groups as (gender, laterality of hearing loss, hearing aid use).

One-way ANOVA test was used to compare quantitative variables (scores of four domains of WHO QOL-BREF questionnaire) between more than 2 groups as (age categories, educational level, occupational status, degree of hearing loss). P-value $\leq 0.05$ was considered significant.

Ethical consideration: Approval from faculty of medicine Ain Shams University, ethical committee was obtained. Administrative approval from Audiology department and Ain Shams University hospitals were taken. Participants were informed about the aims and benefits of the study, verbal consent was used for voluntary participation. Questionnaire used was anonymous; confidentially of data was assured.

Results: Out of 311 interviewed participants, $(52.1 \%)$ were females, $(24.1 \%)$ of the participants were between 18-29 years.Only about half of them reached secondary level of education. $44.1 \%$ have current occupation. Inflammation (chronic otitis media) was found to be the main cause of hearing loss in $40 \%$ of the studied population, followed by presbycusis $(27.3 \%)$.

Most of the participants suffered from bilateral hearing loss (97.4\%) and weren't using a hearing aid as seen in Table (1). As 
forthe effect of hearing impairment on social and emotional adjustment of adults using HHIA tool: significant handicap was found in 94\% regarding emotional domain (Mean \pm S.D $=60.3 \pm 13.4)$, and mild to moderate handicap was found in $52 \%$ of them regarding the social domain (Mean \pm S.D $=43.8 \pm 17.0$ ) Table (2).

The HHIA tool revealed that $(65.3 \%)$ of participants used phone less than they would like, only (5.8\%) avoided groups of people, $(10.6 \%)$ of them had a difficulty when attending a party, about (86.8\%) claimed that they visit their friends and relatives less than they would like, only $(11.6 \%)$ had no difficulty when listening to TV and Radio.

The study results found that $(44.1 \%)$ of participants were satisfied with sleep, more than half were satisfied with their ability to perform their daily activities and their capacity for work. $49.1 \%$ of them were dissatisfied with their friends' support, $(38.3 \%)$ were satisfied with the condition of their living place and only (35.4\%) were satisfied with their transport.

On assessing the QoL using the WHOQOL- Bref; the current study found that $70 \%$ of the participants are satisfied with their lives. However, only $36 \%$ of them reported having a good quality of life from their opinion as seen in Table (3). Table (4) shows that, the environmental domain is the most affected QoL domain with hearing loss (Mean \pm S.D $=56.1 \pm 11.4)$, to be followed by the psychological (Mean \pm S.D $=62.1 \pm 7.6)$ and nearly the physical and social domains are affected equally with hearing $\operatorname{loss}($ Mean \pm S.D=64.4+9.5), (Mean \pm S.D $=65.2 \pm 10.7)$ respectively.

Table (5) shows the effect of different socio-demographic characteristics on the study population, where increase age was found to have a strong effect on lowering QoL mean scores regarding physical, psychological and environmental domains \{statistically significant $\quad(\mathrm{p}$ value $<0.01)\}$. Statistically significant association was reported between educational level of the studied participants and all QoL domains; as educational level increase, better mean scores are observed. Similarly the occupational level, where those working reported higher mean scores than those not working or housewives.

Statistical significant difference was found between who use and do not use hearing aids, regarding the environmental domain with higher mean scores observed among those using hearing aids. However, other factors as gender, type and degree of hearing loss did not show any significant relation with QoL domains. 
Discussion: The current study was conducted with an ultimate goal to participate, along with other future surveys, in setting a national strategy for evaluation, prevention, and control of hearing impairment. In the current study, the mean age of patients was 38.7 and inflammation(CSOM) was the main cause of hearing loss. Similar results was found in a study conducted in Yemen by AL-Mahbashi and Raja'a, in 2011 in which mean age for hearing loss was 37.5 years and inflammation was reported as the main cause as well.

This may be attributed to weak immunity, high prevalence of infectious diseases, poor hygiene and no early detection or management for inflammation, which could be due to seeking traditional healing solutions for chronic suppurative otitis media. ${ }^{(7)}$ In the current study,more than $97.4 \%$ of patients with hearing loss were not using hearing aids. This is very high when compared to patients in Yemen (AL-Mahbashi and Raja'a, 2011), where $91 \%$ of patients with hearing impairment don't use hearing aids. ${ }^{(7)}$

Also, in Australia (Hogan et al., 2009), only $40 \%$ of patients did not use hearing aids. A possible explanation can be that $40 \%$ of the studied population in the current study suffered mild and temporary hearing loss due to $\mathrm{CSOM}$ which is a relative contraindication for hearing aid use. For the rest of patients who suffered sensory neural hearing loss (SNHL) Quality hearing aids are costly and most patients deny their disability. ${ }^{(10)}$

The current study showed that $(65.3 \%)$ of participants used phone less than they would like, only (5.8\%) of them avoided groups of people, $(10.6 \%)$ of them had a difficulty when attending a party, about $(86.8 \%)$ of them claimed that they visit their friends and relatives less than they would like, only $(11.6 \%)$ had no difficulty when listening to TV and Radio. However a study conducted by Weinstein et al in 2015 found that $18 \%$ of subjects were not accustomed to meeting new people, $50 \%$ did not attend religious ceremonies, and 92\% were not accustomed to outdoor dining. ${ }^{(11)}$

The current study found that hearing loss has its effect on all QoL domains (the environmental domain is the most affected followed by the psychological) this consistent with the results of the study carried out by Zhang et al. in 2012 in New Zealand reported hearing loss is associated with poorer QoL scores in every domain, the effects being greatest in the physical and social domains of QoL. ${ }^{(12)}$

The present study found no significant association between degree of hearing impairment and QoL.Mild and moderate 
degree of HL was encountered in around 90\% of all participants and $40 \%$ are inflammatory. With such degree of hearing loss some loudness in the speaker's voice would compensate for the presence of such handicap.

In some studies, the severity of the hearing loss was associated with poorer QoL (Chia et al., 2007; Dalton et al., 2003), ${ }^{(12,13)}$ whereas other studies found no such association(Hogan et al., 2015;Gopinath et al., 2012a). ${ }^{(10,14)}$ The current study showed that there is statistically significant relationship between age and physical, psychological and environmental domains and there is statistically insignificant relationship between age groups as regards social domain.Statistically significant association was reported between educational level of the participants and all QoL domains; as educational level increase, better mean scores are observed. Similarly, the occupational level.

On the other hand, a study in America on recreational firearm users study (Stewart et al., 2002) reveals that QoL significantly decline with age just as hearing loss did. These results are likely linked with hearing status of the respective demographic groups but may also be associated with other factors such as lifestyle and listening needs. ${ }^{(15)}$ The current study found statistically insignificant relationship between degree of hearing impairment and social, physical, psychological and environmental domains.

As previously stated, Mild and moderate degree of HL was encountered in around 90\% of all participants may explain the insignificant relationship. The current study showed that there is statistically insignificant relationship between laterality of hearing impairment and social, physical, psychological and environmental domains.This agrees with a study in Sweden (Hallberg et al., 2008), which reported that persons with unilateral HL did not report significantly lower generic QoL than persons without HL. ${ }^{(16)}$

The current study showed that there is a statistically significant relationship between using hearing aids and environmental domain and that there is a statistically insignificant relationship between using hearing aids and physical, psychological or social domains.Because of the very small $\%$ of hearing aid users in the present(2.6\%) study, these data should be further investigated.

Despite the fact that HL may cause poorer generic QoL, and that using a hearing aid may improve generic QoL, some studies as in Finland by Niemensivu et al. in 2015 suggested that many who are fitted with 
hearing aids, used their hearing aid only to a limited degree.This may be caused by the patients not receiving sufficient help and follow-up to master the hearing aiduse. ${ }^{(17)}$

Study limitations: Limitations of the study were small sample, sampling technique which is purposivewithout randomization, and scarcity of comparable studies.

Conclusion: The social, emotional and environmental aspects of QoL are affected with hearing loss status. Hearing aids helps a lot to improve these aspects enabling the hearing loss patients to have a better QoL.

Acknowledgment: To all the patients that participated in the study for their time and acceptance to participate.

Fund: There is no fund.

Conflict of interest: There is no conflict of interest.

\section{References:}

1. Gates GA and Mills JH. Presbycusis. The Lancet. 2005; 366: 1111-20.

2. World health Organization. Millions of people in the world have hearing loss that can be treated and prevented (2013). Last Acess :August 2018

3. Daniel E. Noise and hearing loss: a review. Journal of School Health. 2007; 77: 225-31.
4. Abdel-Hamid O, Khatib O, Aly A, Morad $\mathrm{M}$ and Kamel S. Prevalence and patterns of hearing impairment in Egypt: a national household survey. Eastern Mediterranean Health Journal. 2007; 13: 1170-80.

5. Ciorba A, Bianchini C, Pelucchi S and Pastore A. The impact of hearing loss on the quality of life of elderly adults. Clinical interventions in aging. 2012; 7: 159.

6. Chisolm TH, Johnson CE, Danhauer JL, et al. A systematic review of healthrelated quality of life and hearing aids: final report of the American Academy of Audiology Task Force on the HealthRelated Quality of Life Benefits of Amplification in Adults. Journal of the American Academy of Audiology. 2007; 18: 151-83.

7. AL-MAHBASHI MY and RAJA'A YA. Quality of life among adult Yemeni patients with hearing loss. The Medical Journal of Cairo University. 2011; 79.

Last Acess :June 2018

8. Organization WH. The world health organization quality of life (WHOQOL)BREF. 2004.

Last Acess :August 2018

9. Weinstein BE, Spitzer JB and Ventry IM. Test-retest reliability of the Hearing 
Handicap Inventory for the Elderly. Ear and Hearing. 1986; 7: 295-9.

10. Hogan A, Phillips RL, Brumby SA, Williams W and Mercer-Grant C. Higher social distress and lower psycho-social wellbeing: examining the coping capacity and health of people with hearing impairment. Disability and rehabilitation. 2015; 37: 2070-5.

11. Weinstein BE, Rasheedy D, Taha HM and FatouhFN. Cross-cultural adaptation of an Arabic version of the 10-item hearing handicap inventory. International journal of audiology. 2015; 54: 341-6.

12. Zhang S, Moyes S, McLean $\mathrm{C}$, et al. Self-reported hearing, vision and quality of life: Older people in New Z ealand. Australasian journal on ageing. 2016; 35: 98-105.

13. Chia E-M, Wang JJ, Rochtchina E, Cumming RR, Newall $\mathrm{P}$ and Mitchell P. Hearing impairment and health-related quality of life: the Blue Mountains Hearing Study. Ear and hearing. 2007; 28: 1-87-95.

14. Gopinath B, Hickson L, Schneider J, et al. Hearing-impaired adults are at increased risk of experiencing emotional distress and social engagement restrictions five years later. Age and Ageing. 2012; 41: 618-23.

15. Stewart M, Pankiw R, Lehman ME and Simpson TH. Hearing loss and hearing handicap in users of recreational firearms. Journal of the American Academy of Audiology. 2002; 13: 160-8.

16. Hallberg LR-M, Hallberg $U$ and Kramer SE. Self-reported hearing difficulties, communication strategiesand psychological general well-being (quality of life) in patients with acquired hearing impairment. Disability and rehabilitation. 2008; 30: 203-12.

17. Niemensivu R, Manchaiah V, Roine RP, Kentala E and Sintonen H. Health-related quality of life in adults with hearing impairment before and after hearing-aid rehabilitation in Finland. International journal of audiology. 2015; 54: 967-75. 
Table (1): Socio-demographic charactristics of hearing impaired individuals in audiology clinics located in Ain Shams University hospital (EI Demerdash)

\begin{tabular}{|c|c|c|}
\hline Socio-demographic charactristics & $\mathbf{N}$ & $\%$ \\
\hline \multicolumn{3}{|l|}{ Age categories } \\
\hline - $18-29$ & 75 & $24.1 \%$ \\
\hline - $\quad 30-39$ & 67 & $21.5 \%$ \\
\hline - $40-49$ & 52 & $16.7 \%$ \\
\hline - $\quad 50-59$ & 44 & $14.1 \%$ \\
\hline - $\quad 60-70$ & 55 & $17.7 \%$ \\
\hline - $\quad>70$ & 18 & $5.8 \%$ \\
\hline \multicolumn{3}{|l|}{ Gender } \\
\hline - $\quad$ Male & 149 & $47.9 \%$ \\
\hline - Female & 162 & $52.1 \%$ \\
\hline \multicolumn{3}{|l|}{ Educational level } \\
\hline - $\quad$ Illiterate & 24 & $7.7 \%$ \\
\hline - Primary & 10 & $3.2 \%$ \\
\hline - Preparatory & 27 & $8.7 \%$ \\
\hline - Secondary & 161 & $51.8 \%$ \\
\hline - University & 89 & $28.6 \%$ \\
\hline \multicolumn{3}{|l|}{ Occupation } \\
\hline - Nonworking/housewife & 174 & $55.9 \%$ \\
\hline - Unskilled manual worker & 20 & $6.4 \%$ \\
\hline - $\quad$ Skilled manual worker ${ }^{* *}$ & 28 & $9.0 \%$ \\
\hline - Trade/ business & 6 & $1.9 \%$ \\
\hline - Semiprofessional/ clerk & 59 & $19.0 \%$ \\
\hline - Professional $^{*}$ & 24 & $7.7 \%$ \\
\hline \multicolumn{3}{|l|}{ Cause of hearing loss } \\
\hline - Inflammatory(CSOM)*** & 126 & $40.5 \%$ \\
\hline - Congenital & 2 & $0.6 \%$ \\
\hline - presbycusis & 85 & $27.3 \%$ \\
\hline - Noise induced & 68 & $21.9 \%$ \\
\hline - Ototoxicity & 30 & $9.6 \%$ \\
\hline - Post-operative, post-traumatic, oto-sclerosis & 0 & $0.0 \%$ \\
\hline \multicolumn{3}{|l|}{ Hearing aid use } \\
\hline - No & 303 & $97.4 \%$ \\
\hline - Yes & 8 & $2.6 \%$ \\
\hline \multicolumn{3}{|l|}{ Type of hearing impairment } \\
\hline - Unilateral & 8 & $2.6 \%$ \\
\hline - Bilateral & 303 & $97.4 \%$ \\
\hline \multicolumn{3}{|l|}{ Degree of hearing impairment } \\
\hline - $\quad$ Mild & 23 & $7.4 \%$ \\
\hline - Moderate & 255 & $82.0 \%$ \\
\hline - Severe & 33 & $10.6 \%$ \\
\hline
\end{tabular}

*Professional: doctor, teacher, lawyer and accountant, ** Skilled workers: driver, worker, guard, carpenter, seller man, butcher and barber

***(CSOM ) \{Chronic Suppative Otitis Media 
Table (2): Description of the effects of hearing impairment on social and emotional adjustment of adults

\begin{tabular}{|c|c|c|}
\hline HHIA Effects & Mean \pm SD & Min - Max \\
\hline $\begin{array}{l}\text { HHIA* total percent } \\
\text { HHIA Social domain percent } \\
\text { HHIA emotional domain percent }\end{array}$ & $\begin{array}{l}52.4 \pm 13.1 \\
43.8 \pm 17.0 \\
60.3 \pm 13.4\end{array}$ & $\begin{array}{l}6.0-94.0 \\
4.2-95.8 \\
7.7-96.2\end{array}$ \\
\hline & No. & $\%$ \\
\hline $\begin{array}{l}\text { HHIA total score categories } \\
\text { - } \quad 0-16 \% \text { (no handicap) } \\
\text { - } 18-42 \% \text { (mild - moderate handicap) } \\
\text { - } \quad 44 \% \text { and more (significant handicap }\end{array}$ & $\begin{array}{c}3 \\
56 \\
252\end{array}$ & $\begin{array}{l}1.0 \% \\
18.0 \% \\
81.0 \%\end{array}$ \\
\hline \multicolumn{3}{|l|}{ HHIA social score categories } \\
\hline $\begin{array}{l}\text { - } \quad 0-16 \% \text { (no handicap) } \\
\text { - } 18-42 \% \text { (mild - moderate handicap) } \\
\text { - } 44 \% \text { and more (significant handicap }\end{array}$ & $\begin{array}{c}4 \\
156 \\
139\end{array}$ & $\begin{array}{c}1.3 \% \\
52.2 \% \\
46.5 \%\end{array}$ \\
\hline \multicolumn{3}{|l|}{ HHIA emotional score categories } \\
\hline $\begin{array}{l}\text { - } 0-16 \% \text { (no handicap) } \\
\text { - } 18-42 \% \text { (mild - moderate handicap) } \\
\text { - } 44 \% \text { and more (significant handicap }\end{array}$ & $\begin{array}{c}2 \\
15 \\
285\end{array}$ & $\begin{array}{l}0.7 \% \\
5.0 \% \\
94.4 \%\end{array}$ \\
\hline
\end{tabular}

* HHIA: The Hearing Handicap Inventory for Adults

Table (3): Participants' opinion towards their health and QoL

\begin{tabular}{|c|c|c|c|}
\hline & & No. & $\%$ \\
\hline \multirow{5}{*}{$\begin{array}{l}\text { Rating perceived quality } \\
\text { of life }\end{array}$} & - Very poor & 1 & $0.3 \%$ \\
\hline & - $\quad$ Poor & 21 & $6.8 \%$ \\
\hline & - Neither poor or good & 170 & $54.7 \%$ \\
\hline & - Good & 112 & $36.0 \%$ \\
\hline & - Very good & 7 & $2.3 \%$ \\
\hline \multirow{5}{*}{$\begin{array}{l}\text { Satisfaction about own } \\
\text { health }\end{array}$} & - $\quad$ Very dissatisfied & 0 & $0.0 \%$ \\
\hline & - Dissatisfied & 30 & $9.6 \%$ \\
\hline & - Neither dissatisfied nor satisfied & 45 & $14.5 \%$ \\
\hline & - $\quad$ Satisfied & 219 & $70.4 \%$ \\
\hline & - Very satisfied & 17 & $5.5 \%$ \\
\hline
\end{tabular}


Table (4): Description of four domains of WHO QOL-BREF questionnaire

\begin{tabular}{|l|r|r|}
\hline \multicolumn{1}{|c|}{ Domains of Quality of Life } & Mean \pm SD & Min - Max \\
\hline Domain 1: Physical & $64.4 \pm 9.5$ & $31.4-82.9$ \\
\hline Domain 2: Psychological & $62.1 \pm 7.6$ & $46.7-83.3$ \\
\hline Domain 3: Social & $65.2 \pm 10.7$ & $26.7-93.3$ \\
\hline Domain 4:Environmental & $56.1 \pm 11.4$ & $27.5-90.0$ \\
\hline
\end{tabular}


Table (5): Studying the effect of socio-demographic charactristics of the studied group on the four domains of WHO QOL-BREF questionnaire

\begin{tabular}{|c|c|c|c|c|}
\hline & $\begin{array}{l}\text { Physical } \\
\text { domain }\end{array}$ & $\begin{array}{c}\text { Psychological } \\
\text { domain }\end{array}$ & $\begin{array}{c}\text { Social } \\
\text { domain }\end{array}$ & $\begin{array}{c}\text { Environmental } \\
\text { domain }\end{array}$ \\
\hline \multicolumn{5}{|l|}{ Gender $^{\dagger}$} \\
\hline - $\quad$ Male & $63.93+10.62$ & $62.06 \pm 8.00$ & $65.88 \pm 10.33$ & $55.77 \pm 12.02$ \\
\hline - $\quad$ Female & $64.83+8.43$ & $62.12+7.15$ & $64.55+10.95$ & $56.42+10.91$ \\
\hline P-value & 0.406 & 0.943 & $0 . \overline{341}$ & $0 . \overline{6} 19$ \\
\hline \multicolumn{5}{|l|}{ Age categories \# } \\
\hline - $18-29$ & $67.89 \pm 8.04$ & $64.93 \pm 7.56$ & $68.41 \pm 11.05$ & $55.2 \pm 10.56$ \\
\hline - $30-39$ & $68.06 \pm 7$ & $63.83 \pm 7.66$ & $66.26 \pm 10.39$ & $59.66 \pm 10.34$ \\
\hline - $40-49$ & $62.64+9.53$ & $61.03+7.91$ & $64.87 \pm 12.46$ & $52.5+10.62$ \\
\hline - $50-59$ & $64.09 \pm 8.72$ & $60.76+6.78$ & $63.48+9.59$ & $59.2 \pm 10.03$ \\
\hline - $\quad 60-70$ & $61.92 \pm 9.15$ & $60 \pm 6.22$ & $64.3 \pm 9.86$ & $56.55 \pm 11.28$ \\
\hline - $\quad>70$ & $49.68 \pm 9.56$ & $56.48+5.99$ & $62.22 \pm 8.07$ & $48.19 \pm 17.49$ \\
\hline P-value & $0.000 *$ & $0.000^{*}$ & $0.4 \overline{55}$ & $0.000 *$ \\
\hline \multicolumn{5}{|l|}{ Educational level ${ }^{\#}$} \\
\hline - $\quad$ Illiterate & $59.4 \pm 7.81$ & $56.39 \pm 3.25$ & $61.33 \pm 10.73$ & $51.15 \pm 11.75$ \\
\hline - $\quad$ Primary & $59.43 \pm 12.03$ & $54+3.44$ & $55.33+10.91$ & $49+9.29$ \\
\hline - Preparatory & $62.01 \pm 6.57$ & $60.12 \pm 8.14$ & $61.87 \pm 12.98$ & $53.06 \pm 11.42$ \\
\hline - Secondary & $65.25 \pm 9.96$ & $62.09 \pm 7.07$ & $64.87 \pm 10.02$ & $54.97 \pm 11.09$ \\
\hline - University & $65.49 \pm 9.09$ & $65.13 \pm 7.75$ & $68.92 \pm 9.22$ & $61.24 \pm 10.49$ \\
\hline P-value & $0.009^{*}$ & $0.000^{*}$ & $0.000 *$ & $0.000 *$ \\
\hline \multicolumn{5}{|l|}{ Occupational level $^{\#}$} \\
\hline - Nonworking/housewife & $62.96 \pm 10.23$ & $60.79 \pm 6.72$ & $63.16 \pm 10.53$ & $54.96 \pm 11.8$ \\
\hline - Unskilled manual worker & $61.43+9.66$ & $59.17 \pm 9.17$ & $63.14+14.93$ & $50.38+11.54$ \\
\hline - $\quad$ Skilled manual worker & $67.45+7.27$ & $59.76+6.21$ & $63.59 \pm 7.83$ & $51.16+8.59$ \\
\hline - $\quad$ Trade/ business & $65.24+7.32$ & $67.78+7.79$ & $70.67 \pm 3.65$ & $62.5 \pm 14.32$ \\
\hline - Semiprofessional/ clerk & $67.75 \pm 7.49$ & $66.05 \pm 7.31$ & $68.93 \pm 9.39$ & $60.97 \pm 8.01$ \\
\hline - $\quad$ Professional & $65.36+9.09$ & $65.56+8.94$ & $69.39+11.2$ & $61.46+12.02$ \\
\hline P-value & $0.005^{*}$ & $0.000^{*}$ & $0.005^{*}$ & $0.000 *$ \\
\hline \multicolumn{5}{|l|}{ Laterality of hearing loss ${ }^{\dagger}$} \\
\hline - Unilateral & $66.79 \pm 6.65$ & $62.08+3.54$ & $56.00 \pm 8.94$ & $55.31+8.18$ \\
\hline - $\quad$ Bilateral & $64.34 \pm 9.60$ & $62.09 \pm 7.64$ & $65.37 \pm 10.63$ & $56.13 \pm 11.53$ \\
\hline P-value & $0 . \overline{475}$ & 0.998 & $0 . \overline{052}$ & $0 . \overline{842}$ \\
\hline \multicolumn{5}{|l|}{ Degree of hearing loss ${ }^{\#}$} \\
\hline - Mild & $68.2 \pm 7.72$ & $64.64 \pm 8.21$ & $68.21 \pm 11.6$ & $56.63 \pm 10.27$ \\
\hline - $\quad$ Moderate & $64.24 \pm 9.43$ & $61.99 \pm 7.53$ & $65.36 \pm 10.67$ & $56.13 \pm 11.16$ \\
\hline - $\quad$ Severe & $63.03+11.06$ & $61.11 \pm 7.2$ & $61.94+9.73$ & $55.61+14.4$ \\
\hline P-value & 0.110 & 0.201 & 0.191 & 0.946 \\
\hline \multicolumn{5}{|l|}{ Hearing aid use $^{\dagger}$} \\
\hline - $\quad$ No & $64.29+9.52$ & $62.10+7.58$ & $65.16 \pm 10.58$ & $55.84+11.29$ \\
\hline - Yes & $68.57 \pm 9.78$ & $61.67 \pm 7.35$ & $65.56 \pm 14.86$ & $66.25 \pm 13.43$ \\
\hline P-value & $0 . \overline{211}$ & $0.8 \overline{73}$ & $0 . \overline{929}$ & $0.011 *$ \\
\hline
\end{tabular}

$(\dagger)$ independent $t$ test, $(\#)$ ANOVA test, $(*)$ statistically significant 
جودة الحياة بين مرضى ضف السمع في عيادة السمعيات الخارجية بمستثفيات جامعة عين شمس

شيماء سلطان- داليا سوس- مهاودان- نجوي هز اع- ضياء عبد الحميد

الخلفية: يعد ضعف السمع عند البالغين أحد الأمر اض المزمنة الاكثر شيوعًا في جميع أنحاء العالم. يرتبط ضعفالسمع بانخفاض جودة الحياة، و عادة ما يسبب صعوبة في فهم الكلام ، ويؤثر على الحالة المعرفية والعاطفية، انخفاض الدخل وزيادة معدل الاصابة بالأمر اض والوفيات. ينز ايد انتشار ضعفالسمع بسبب زيادة التعرض للضوضاء المفرطة وزيادة متوسط العمر المتوقع والتدخين و المخاطر القلبية الوعائية والعدوى.الهذف: تقييم نوعية الحياةلضعف السمع بين البالغين في العيادات الخارجية في مستشفيات جامعة عين شمس وتحديد أهم المحددات التي تؤثر على جودة الحياةلضعف السمع بين المرضى البالغين. المنهجية وطريقة البحث : أجريت در اسة مقطعية على 311 مريض يعانون من ضعفالسمع في عيادات السمع الموجودة في مستشفى جامعة عين شمس. تم جمع البيانات باستخداماستبيان. النتائج: من بين 311 مشاركاً تمت مقابلتهم ، كانت (52.1\%) من الإناث ، (24.1\%) من المشاركين بين 18-29 سنة. وجد أن الالتهاب هو السبب الرئيسي لضعف السمع في 40٪ من السكان الذين خضعو ا للار اسة. المجال البيئي هو المجالأكثر تضررا مع ضعفالسمع للمشاركين مع تأثير إحصائي كبير لاستخدام الوسائل السمعية على تحسين جودة الحياة.الخلاصة: يجب أن يتم الكثف المبكر في المر اكز الصحية الأولية لتشخيص ضعف السمع ، وبالتالي التدخل الفوري للحفاظ على جودة الحياة بين المرضى الذين يعانون من ضعف السمع. 